\title{
ASSESSMENT OF DIRECT INVESTMENT INFLUENCE ONTO ECONOMIC RESULTS OF COPPER INDUSTRY ENTERPRISES
}

\author{
Stanislav Victorovich PRIDVIZHKIN \\ Department of Price Formation in Construction and Industry \\ Ural Federal University named after the first President of \\ Russia B.N. Yeltsin \\ Yekaterinburg, Russian
}

\author{
Oleg Victorovich BAZHENOV \\ Department of Accounting, Analysis and Audit \\ Ural Federal University named after the first President of \\ Russia B.N. Yeltsin \\ Yekaterinburg, Russian \\ 6819@1ist.ru
}

\begin{abstract}
The paper defines and characterizes the direction and power of influence that different factors exert on the results of activities of companies in the copper industry, defined in terms of company's revenue. A special emphasis was put on the evaluation of the influencing power of direct investment. To that end, the authors consistently solved the following tasks: 1) analysis and characteristic of the market structure of the Russian copper industry; 2) building a regression econometric model of dependence of company's earnings on direct investment. It is built for the principal companies of the Russian copper industry using the analysis of panel data for 87 companies. Further, this model is evaluated using the least square method; 3) interpretation of the results, obtained with the economic statistical model. The methodology of the work includes comparative analysis and generalization of information obtained from different sources. A content analysis of recent Russian and foreign analytical publications was undertaken. Statistical (panel) data were analyzed and a regression model was built, which uses the revenues of a copper industry company as a dependent variable, while direct investment, capital and material inventory at the company's premises served as independent variables. The model was further assessed with the least square method. The research allows concluding that the direct investment plays an important role in the company's business, but at the level of the industry, they are accompanied by negative internal effects due to existing volatile movements, including presence of major players in the market.
\end{abstract}

Keywords - direct investment, capital, copper industry, least square method, regression analysis, statistical economic modeling

\section{INTRODUCTION}

Presently, the Russian economy goes through a significant decline, caused mainly by macroeconomic factors, such as the reduction in oil prices, falling exchange rate of the national currency, limited access to foreign sources of financing among

\author{
Margarita Karpovna KOZHEVNIKOVA \\ Department of Price Formation in Construction and Industry \\ Ural Federal University named after the first President of \\ Russia B.N. Yeltsin \\ Yekaterinburg, Russian d \\ Denis Vitalyevich BAYEV \\ Department of International Economics \\ Ural Federal University named after the first President of \\ Russia B.N. Yeltsin \\ Yekaterinburg, Russian
}

others. Besides that, according to United Nations Conference on Trade and Development and the Federal National Statistics Office, there is a reduction of direct investment inflow (including foreign direct investment) into Russia, and in some industries, investment outflow is observed [1, 2]. Direct investment is usually considered among the most important transactions, significantly influencing economic development of the country as a whole and that of separate industries. On the other hand, some studies show that the effect of the direct investment onto the activities of a company and industry as a whole is not always positive [3-7].

The main objective of this study is to determine aspects and the degree of influence of direct investment into Russian copper industry enterprises, as well as causes of such influence.

For the purpose of this study, let us consider such direct investment as an investment of capital into creation, acquisition, expansion, as well as reconstruction and modernization of permanent assets with the aim of obtaining additional income or supporting it at a stable level.

A foreign direct investment (FDI) is investments that provide an investor with control over economic activities of an enterprise located in a different country. Besides, FDI facilitate transfer of technologies, management methods, licensing agreements, physical capital, financial assets, control over material supply, which serves as a primary mean of investor's control [8].

Theoretical description of the direct investment, including a foreign one is provided by international trade theories (Ricardo-Viner, Heckscher-Ohlin, Heckscher-OhlinSamuelson) as well as by Dunning's eclectic paradigm [9]. Brainard's gravity model of trade may be used to explain the FDI flows; this model considers the influence of the distance 
between the countries and sizes of their economies on the amount of foreign direct investment [10].

Similar studies, covering influence of direct investments into different sectors of developing and transitional economies, were conducted by J. Konings, S.L. Brainard, S. Djankov and B. Hoekman, B. Smarzynska, K. ZukowskaGagelmann and others.

Besides that, it is necessary to accentuate external and internal effects of foreign direct investment. The external effects include influence of the investment on activities of those national companies, which operate without participation of foreign capital and include market effects and diffusion of operating resources. The market effects may be positive or negative, while effects of the diffusion are always positive (transfer of managerial and production resources and marketing technologies). The negative effects appear when increased competition from foreign and foreign-owned companies influences (reduces) the market share of national companies. Besides that, companies directly involved in the investment process (including those receiving foreign direct investment) for development of their business have an advantage over their competitors due to transfer of technologies, know-how, management and marketing methods.

The internal effects include the influence on the economic activities of the companies [8].

The most significant work dedicated to studying intrasectoral external effects is the work of J. Konings [5], which is based upon evaluation of the influence exerted by certain factors on the sectors of developing and transitional economies. Konings has determined that the direct investment (foreign direct investment) may have negative market effects, which is evident from the structure of a market among other things.

\section{RESEARCH METHODOLOGY}

To analyze Russian copper industry, 87 companies, which have been established in the copper production sector, were selected from the SPARK data base.

At the first stage, market capacity was determined to confirm Konings' hypothesis about a link between the negative market effects from DI and the market structure. This study covers a period from 2011 to 2015 .

Thus, the authors determined the market capacity as the total revenue from sales of products of all the enterprises. Besides that, subsidiaries of several holdings were excluded from the sample (e.g., UGMK-Holding, due to the fact that financial statements are furnished in consolidation).

In 2015, the largest producers of copper in the Russian market were GMK Norilsk Nickel, Uralelektromed (a part of UGMK-Holding) and RCC (Russian Copper Company).

To determine the concentration level, the following indicators were calculated: concentration indexes, HerfindahlHirschman Index, Hall-Tideman index and the entropy index [11]. The results are given in Table 1.
TABLE I.

DYNAMICS OF MARKET CONCENTRATION INDICATORS, 20112015 .

\begin{tabular}{|c|l|l|l|l|l|l|}
\hline \multirow{2}{*}{ Property } & \multicolumn{5}{|c|}{ Value } & \multicolumn{2}{c|}{ Interpretation } \\
\cline { 2 - 6 } & 2011 & 2012 & 2013 & 2014 & 2015 & \\
\hline $\begin{array}{c}\text { Concentrati } \\
\text { on index } \\
\text { CR2 }\end{array}$ & 0.79 & 0.80 & 0.77 & 0.77 & 0.81 & $\begin{array}{l}\text { High level of } \\
\text { concentration, because } \\
\text { the indicator is in the } \\
(0.70 ; 1.00) \text { range. }\end{array}$ \\
\hline $\begin{array}{c}\text { Concentrati } \\
\text { on index } \\
\text { CR3 }\end{array}$ & 0.93 & 0.94 & 0.92 & 0.91 & 0.93 & $\begin{array}{l}\text { High level of } \\
\text { concentration, because } \\
\text { the indicator is in the } \\
(0.70 ; 1.00) \text { range. }\end{array}$ \\
\hline $\begin{array}{c}\text { Concentrati } \\
\text { on index } \\
\text { CR4 }\end{array}$ & 0.95 & 0.95 & 0.93 & 0.93 & 0.95 & $\begin{array}{l}\text { High level of } \\
\text { concentration. }\end{array}$ \\
\hline $\begin{array}{c}\text { Herfindahl- } \\
\text { Hirschman } \\
\text { Index (HHI) }\end{array}$ & 0.39 & 0.42 & 0.36 & 0.34 & 0.38 & $\begin{array}{l}\text { High level of market } \\
\text { concentration. }\end{array}$ \\
\hline $\begin{array}{c}\text { Hall- } \\
\text { Tideman } \\
\text { Index (HTI) }\end{array}$ & 0.364 & 0.373 & 0.318 & 0.304 & 0.347 & $\begin{array}{l}\text { The value is quite high, } \\
\text { thus, the market is } \\
\text { highly concentrated. }\end{array}$ \\
\hline $\begin{array}{c}\text { Entropy } \\
\text { Index E }\end{array}$ & 1.24 & 1.20 & 1.34 & 1.38 & 1.27 & $\begin{array}{l}\text { The value is above 1, } \\
\text { thus, the market is } \\
\text { highly concentrated. }\end{array}$ \\
\hline
\end{tabular}

Thus, from these results, it is possible to conclude that the market is highly concentrated. Furthermore, it may be defined as an oligopoly because there are three companies with quite large market shares (Norilsk Nickel, UGMK-Holding, Russian Copper Company). Values of the concentration indexes (CR2, CR3, CR4) vary insignificantly, but they all show the highest value for 2015. A reduction in concentration was observed in 2012 and 2013.

From this research, it is evident that the share of large companies grows, as the positive dynamics of the market concentration indicators shows. These results support the hypothesis of presence of the negative intra-industry effects, which will be additionally tested at the next stage.

The next stage of the study is econometric analysis. The authors have selected 87 copper producers operating from 2007 to 2015. The maximum sample size was 792 observations; however, due to the difference in estimation variants, the number of observations included in the study varied as well. Konings' econometric model was used as a basis. Several variants of the model were used and evaluated using the least square method to avoid such problems of statistical nature as multicollinearity and heteroscedasticity. Revenue, reflecting the company's efficiency in monetary terms, serves as a dependent variable.

\section{RESULTS}

Building the econometric model starts from studying the matrix of paired correlation coefficients for the variables (Table 2), which values show correlation between the independent variables allowing for conclusion about possibility of multicollinearity in the model. The coefficients also demonstrate the link between the dependent variable and 
the independent ones, thus the variables may be significant during the evaluation.

TABLE II. PAIRED COEFFICIENT MATRIX FOR REVENUE, MATERIALS, CAPITAL, MANPOWER AND DI.

\begin{tabular}{|c|c|c|c|c|c|}
\hline & $\mathrm{Y}$ & $\mathrm{M}$ & $\mathrm{K}$ & $\mathrm{L}$ & $\mathrm{DI}$ \\
\hline $\mathrm{Y}$ & 1.000000 & 0.847425 & 0.772660 & 0.572993 & 0.386992 \\
\hline $\mathrm{M}$ & 0.847425 & 1.000000 & 0.898441 & 0.459931 & 0.383407 \\
\hline $\mathrm{K}$ & 0.772660 & 0.898441 & 1.000000 & 0.381044 & 0.395596 \\
\hline $\mathrm{L}$ & 0.572993 & 0.459931 & 0.381044 & 1.000000 & 0.272121 \\
\hline $\mathrm{DI}$ & 0.386992 & 0.383407 & 0.395596 & 0.272121 & 1.000000 \\
\hline
\end{tabular}

At the next stage, the link between the dependent and variables is shown in a graphic form as a cloud of observations.

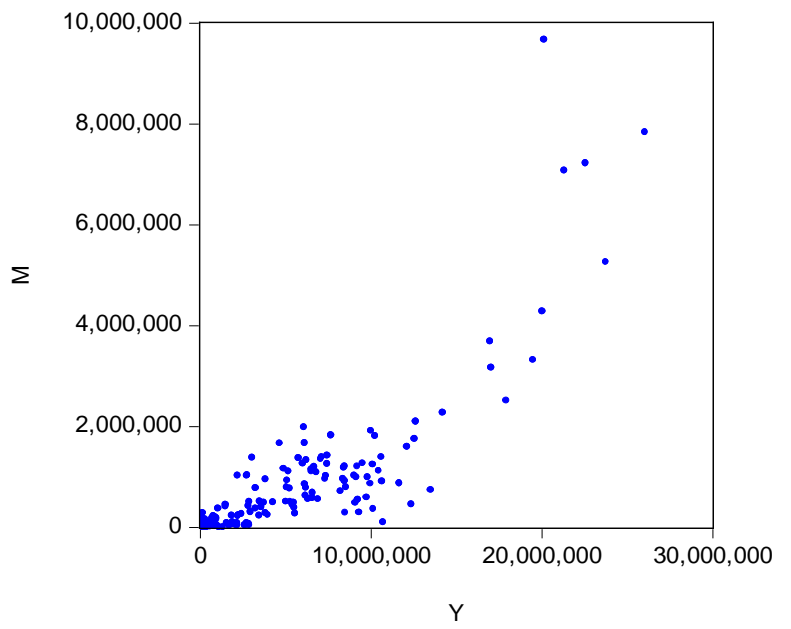

Fig. 1. Cloud of observations for dependence between the revenue and material stock.

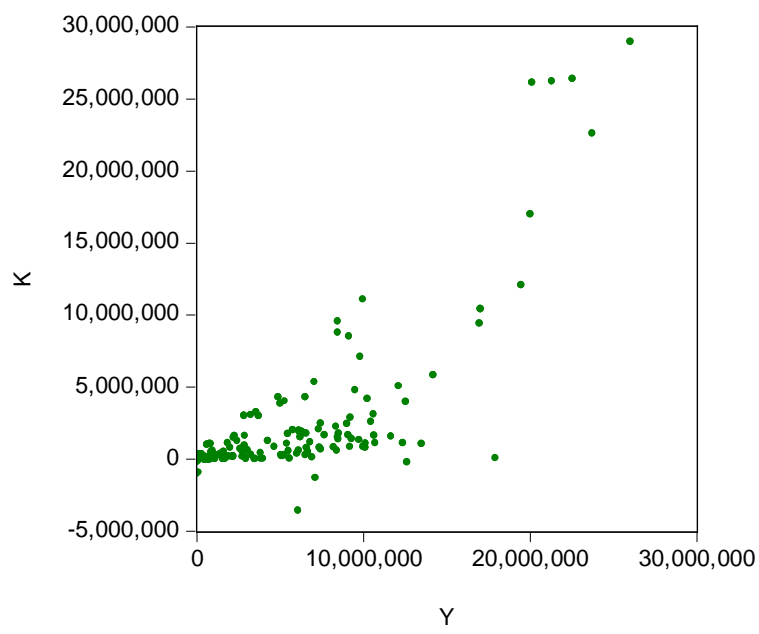

Fig. 2. Cloud of observations for dependence between the revenue and capital.

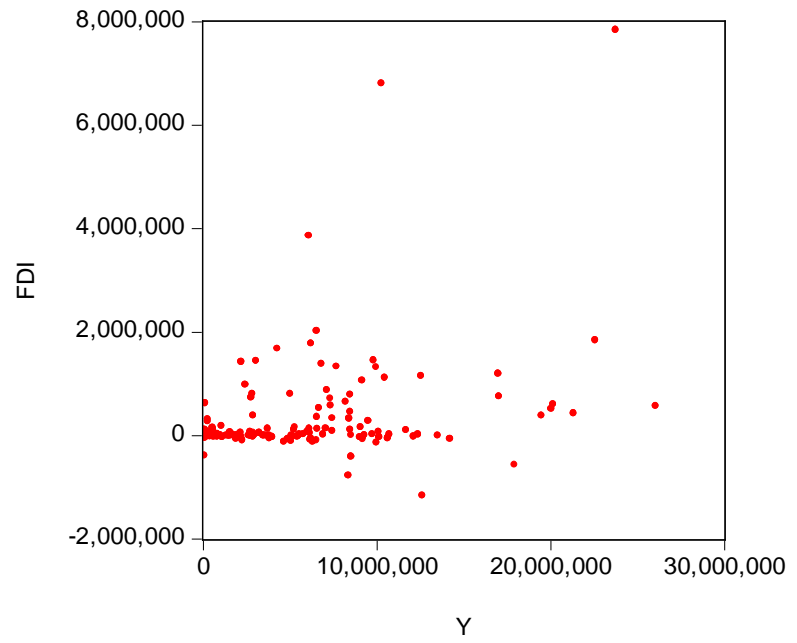

Fig. 3. Cloud of observations for dependence between the revenue and DI.

Thus, from the graphs in Figures 1, 2, 3, it is evident that the dependence is linear or near-linear.

Then an adapted Konings' model is introduced:

$$
Y_{i t}=\beta_{0}+\beta_{1} D I_{i t}+\beta_{2} K_{i t}+\beta_{3} M_{i t}+\beta_{4} L_{i t}+\varepsilon
$$

where $Y_{i t}$ is a dependent variable, signifying revenue of the $i$-th company for period $t$ and independent variables:

$D I_{i t}$ is a direct investment amount, reflecting direct effects;

$K_{i t}$ is the capital of the company during the period;

$M_{i t}$ is a material stock amount used in the company during the period;

$L_{i t}$ is a dummy variable reflecting the average manpower in the range from 1 to 12 , where 1 is $5-15$ employees and 12 is over 5,000 employees.

The next stage in building the econometric model is to logarithmize the function (1) from the results of graphical analysis shown in Figures 1-3 and to exclude the $\mathrm{L}$ variable (average manpower) for being not significant (Table 3):

$$
\ln Y_{i t}=\beta_{0}+\beta_{1} \ln D I_{i t}+\beta_{2} \ln K_{i t}+\beta_{3} \ln M_{i t}+\varepsilon .
$$

The next stage is analysis of a regression comprised of the variables showing an increase of the logarithms to evaluate the external effects:

$$
\begin{aligned}
& \Delta \ln Y_{i t}=\beta_{0}+\beta_{1} \Delta \ln K_{i t}+\beta_{2} \Delta \ln M_{i t}+ \\
& \beta_{3} \Delta \ln D I_{i t}+\varepsilon_{i t}
\end{aligned}
$$

Variable $D I_{i t}$ is added to Equation 4 to evaluate direct effects from direct investments:

$$
\begin{aligned}
& \Delta h Y_{i t}=\beta_{0}+\beta_{1} \Delta h K_{i t}+\beta_{2} \Delta h M_{i t}+\beta_{3} D I_{i t}+ \\
& \beta_{4} \Delta h D I_{i t}+\varepsilon_{i t}
\end{aligned}
$$


where $D I_{i t}$ is a share of DI at a certain enterprise, reflecting direct effects of investment into its production volume.

The results of regression model evaluation are shown in Table 3.

TABLE III. RESULTS OF EVALUATION OF MNK LINEAR REGRESSION MODEL.

\begin{tabular}{|c|c|c|c|c|}
\hline \multirow{2}{*}{ Variable } & \multicolumn{4}{|c|}{ Equation } \\
\hline & 1 & 2 & 3 & 4 \\
\hline $\mathrm{C}:$ & 7649104* & $7.173497 * * *$ & 0.061071 & 0.013315 \\
\hline Capital & $0.244493 * * *$ & 0.176462 & 0.061819 & -0.034346 \\
\hline Materials & $0.837834^{*}$ & $0.487848 * * *$ & $1.050014 * * *$ & 1.167741 **** \\
\hline $\begin{array}{c}\text { Direct } \\
\text { Investment }\end{array}$ & $\begin{array}{c}- \\
1.241092 * * * \\
\end{array}$ & $-0.111293 *$ & - & -0.011788 \\
\hline Manpower & 76182.39 & - & - & - \\
\hline $\begin{array}{c}\text { Changes in } \\
\text { Direct } \\
\text { Investment }\end{array}$ & - & - & $0.00553 *$ & $0.052643 *$ \\
\hline $\mathrm{R}^{2}$ & 0.984678 & 0.92663 & 0.874936 & 0.888909 \\
\hline $\mathrm{R}^{2}$-adjusted & 0.979935 & 0.88955 & 0.83006 & 0.830096 \\
\hline
\end{tabular}
significance level, $* * *-1 \%$ significance level.

\section{CONCLUSIONS.}

The results shown in Table 3 for each variant of the model may be interpreted in the following way. The determination coefficient for the first variant is 0.984678 , meaning that the variables included in the model explain $98.5 \%$ of variation in the dependent variable. Increasing the capital by 1,000 rubles leads to the growth of the revenue by 244 rubles. Increasing the volume of material stocks by 1,000 rubles in monetary terms leads to the growth of the revenue by 838 rubles. Increasing the amount of DI by 1,000 leads to the reduction of the revenue by 1,241 rubles. Changing the manpower indicator by 1 leads to the growth of the revenue by 76182 rubles, but this variable was excluded from the study due to its statistically insignificant influence on the financial results of a company (the dummy variable is significant at a $90 \%$ level).

Variant (2) may be interpreted in the following way: an increase of capital by $1 \%$ leads to the $17.65 \%$ growth of the revenue; an increase in material stocks by $1 \%$ leads to the $48.78 \%$ growth in the revenue; an increase in the DI amount by $1 \%$ leads to the reduction of the revenue by $11.13 \%$. These three factors explain $92.66 \%$ of variation. Equations (3) and (4) are interpreted in the similar way.

Thus, the most significant variables influencing the results of the copper industry enterprises are material stocks and direct investments. The interpretation of the model's results shows that, independently of model's variations, DI has a negative impact onto the revenue in the industry. Thus this fact attests to existence of negative internal effects which may be caused by insufficient technical and technological development of small companies (many of which are exclusively concerned with processing of copper-containing salvage); movement of specialists to larger companies (parts of vertically integrated holdings like Norilsk Nickel, UGMKHolding and RCC) due to better employment conditions; inefficient management methods and the underdeveloped marketing strategy. Besides that, some companies fail when competing with large companies having foreign direct investments. Moreover, even the large copper producers show underutilization of production facilities. Annual accounts of Uralelectromed for 2015 show that refined copper production facilities (copper cathodes) were underutilized by $3.7 \%$; electrolytic copper powder production was underutilized by $54.3 \%$, blister copper production was underutilized by $30.1 \%$ [12]. Consequently, under the existing market conditions, large direct investments for most small copper producers will not only be useless for increasing the economic results, but are actually unwanted due to their negative influence. Speaking of large holdings, due to existing unused capacities in blister copper production, it is desirable to focus investment activities on development of the further processing of copper.

The results of this research are supported by a number of similar works aimed at studying the influence that direct investments exert on different sectors of economy in Central and Eastern Europe [13].

\section{References}

[1] Federal Statistics Office, Retrieved from http://www.gks.ru/

[2] United Nations conference on Trade and Development. World Investment Report 2016: Annex Tables, Retrieved from http://unctad.org/en/Pages/DIAE/World\%20Investment\%20Report/Anne $\mathrm{x}$-Tables.aspx

[3] S.M. Kadochnikov, I.M. Drapkin, N.B. Davidson, A.A. Fedyunina, Influence of Foreign Direct Investment onto Diversification of the Economy: Modeling of Vertical External Effect Under Condition of Heterogeneity of Companies, Vestnik UpFU (Annals of Urals Federal University). Series: Economy and management, № 5, pp. 82-105, 2012.

[4] S. Djankov, B. Hoekman, Foreign investment and productivity growth in Czech enterprises, The World Bank Economic Review, Vol. 14(1), pp. 49-64, 2000.

[5] J. Konings, The effect of foreign direct investment on domestic firms: Evidence from firm-level panel data in emerging economies, Economics of Transition, Vol. 9(3), pp. 619-633, 2001.

[6] B.K. Smarzynska, Determinants of spill overs from foreign direct investment through backward linkages, The World Bank, July 2002, Mimeo.

[7] K. Zukovska-Gagelmann, Productivity spill overs from foreign direct investment in Poland, Economic Systems, Vol. 24(3), pp. 223-256, 2000.

[8] S.M. Kadochnikov, Foreign Direct Investment: Microeconomic Analysis of Prosperity Effects, Saint Petersburg: Ekonomicheskaya Shkola, 2002, p. 267.

[9] I.M. Drapkin, O.C. Mariyev, K.V. Chukavina, A Quantitative Evaluation of Import And Export Potential of the Foreign Direct Investment in the Russian Economy with a Gravity Approach, Journal of New Economic Association, № 4, pp. 75-95, 2015.

[10] S.L. Brainard, An Empirical Assessment of the Proximity Concentration Tradeoff between Multinational Sales and Trade, American Economic Review, Vol. 87(4), pp. 520-544, 1997.

[11] N.M. Rozanova, Theory of Sectoral Markets, Part 1, Moscow: Urait, $2015,346 \mathrm{p}$.

[12] Annual closing accounts of Uralelectromed, Retrieved from http://www.e-disclosure.ru/portal/files.aspx $? i d=2003 \&$ type $=2$

[13] Miguel Eduardo Sánchez-Martín, Rafael de Arce, Gonzalo Escribano. Do changes in the rules of the game affect FDI flows in Latin America? 
A look at the macroeconomic, institutional and regional integration determinants of FDI, European Journal of Political Economy, 34, pp.
279-299, 2014. 